\title{
PERAN KEAHLIAN TEKNOLOGI PROSES DAN SINTESIS BAHAN DALAM MENDUKUNG INDUSTRI NUKLIR DI INDONESIA
}

\author{
KUSNANTO \\ Jurusan Teknik Fisika, Fakultas Teknik \\ Universitas Gadjah Mada
}

\begin{abstract}
Abstrak
PERAN KEAHLIAN TEKNOLOGI PROSES DAN SINTESIS BAHAN DALAM MENDUKUNG INDUSTRI NUKLIR DI INDONESIA. Energi telah menjadi basic need, yang setara dengan kebutuhan pangan. Dengan pandangan jauh ke depan, kini sudah tiba saatnya untuk mengupayakan pengurangan ketergantungan pada sumber energi primer fosil dan dengan serius mengembangkan sumber energi primer baru yaitu energi nuklir, sinergi dengan pengembangan energi baru dan terbarukan yang lain. Pengembangan reaktor maju menjadi mutlak diperlukan bila energi nuklir akan tetap digunakan sebagai andalan teknologi pemenuhan energi. Peluang untuk mengembangkan industri proses bahan semakin terbuka di Indonesia. Kekayaan alam, mineral dan energi merupakan modal besar bila ditopang dengan kemampuan penguasaan teknologi dan kebijakan pemerintah yang berpihak pada kemampuan dan kemandirian bangsa. Bila hydrogen diproduksi menggunakan reaktor maju dapat diproduksi secara komersial, dapat dipastikan kebutuhan zircon oxide, yang merupakan produk antara industri zirconium logam, akan sangat tajam meningkat kebutuhannya, yaitu untuk fuel cell. Fuel cell jenis SOFC diyakini paling efisien untuk digunakan sebagai alat konversi energi yang menggunakan bahan bakar hydrogen. Agar kemandirian bangsa ini dapat terwujud, dibutuhkan sumber daya manusia yang memiliki keahlian teknologi proses. Keahlian tidak dapat diperoleh hanya melalui pendidikan formal di perguruan tinggi. Keahlian diperoleh melalui 3 tahapan yaitu: a) Pendidikan; b) Pelatihan c) Pengalaman kerja. Pelatihan dan pengalaman kerja memiliki kontribusi besar terhadap keahlian seseorang. Oleh karena itu sertifikasi keahlian/profesi yang terdiri atas aspek pelatihan atau pengalaman kerja menjadi hal-hal yang diperlukan untuk memenuhi kebutuhan di atas.

Kata kunci : Teknologi proses, sintesis bahan, industri nuklir
\end{abstract}

\begin{abstract}
THE ROLE OF VOCATION OF PROCESS TECHNOLOGY AND MATERIAL SYNTHESIS IN ORDER TO SUPPORT NUCLEAR INDUSTRIES IN INDONESIA. Energy has become a basic need, which is comparable to the food requirement. With regard to forecast to the future, it is a time to visualize a reduction of dependency on the primary energy source i.e. fossil fuel, and seriously enhance a development of another new source of energy, that is a nuclear energy, which is synergically extend with other new and renewable energy sources. Development of an advanced reactor will be necessary if the nuclear energy
\end{abstract}


is still to be the main choice to fulfill the energy requirement. An opportunity to extend material process industries in Indonesia is increasingly opened. Natural resources, i.e. mineral and energy sources, will be a big capital invesment when it is supported by an ability of grasping technology and also the government policy that is in favor to the ability and independency of the nation. If hydrogen production is commercially produced by an advanced reactor, surely that the requirement of zircon oxide as a fuel-cell which is an intermediate product of industry of zirconium metal will increase significantly. SOFC, a kind of fuel cell, is believed to be the most effective fuel cell as a converter energy when hydrogen used as a fuel energy source. In order to realize this independency of Indonesian nation, it is required knowledgeable, expertized and skilled human resourses in the process technology field. These expertized human resources can not be prepared by a formal education in collages/universities only, but also through 3 (three) steps of training, i.e. education, skilled/ professional training and working experience. The last two steps have a large contribution to the personal expertizes. Therefore, skilled/ professional certification of someone, that consist of professional training and working experienced will be necessary for the above requirements. formal education, professional training, working experience

Keywords : Process technology, material synthesis, nuclear industries

\section{PENDAHULUAN}

Energi sebagai salah satu komponen pendukung pembangunan nasional, terutama perekonomian, pada saat ini telah membuktikan perannya yang sangat penting. Standard hidup suatu bangsa sampai sat ini masih dihitung antara lain dengan tingkat konsumsi energi bangsa tersebut. Rakyat di negara maju relatif tinggi tingkat kebutuhan/konsumsi energinya, lebih mampu membayar energi, dibandingkan dengan negara-negara berkembang. Negara maju dinilai lebih hemat menggunakan energi daripada negera berkembang, karena mayoritas penggunaan energi untuk industri, sektor-sektor produktif dari pada negara berkembang yang masih lebih berorientasi pada penggunaan energi untuk sektor rumah tangga. Energi secara fundamental kenyataan hidup sehari-hari telah menjadi basic need, yang setara dengan kebutuhan pangan.

Sumber energi yang digunakan hingga saat ini lebih banyak berorientasi pada penggunaan energi fosil, terutama minyak dan gas bumi. Kedua sumber energi tersebut masih digunakan sebagai andalan mendukung devisa negara. Batubara yang cadangannya masih relatif banyak dibanding minyak dan gas bumi, digunakan menggunakan teknologi yang terbatas, belum dikonversi menjadi bahan bakar atau bahan baku industri yang lebih memiliki nilai tambah. Batubara selain dieksport, saat ini mayoritas digunakan untuk pembangkit listrik. Pemanfaatan energi baru dan terbarukan (tenaga angin, gelombang laut, hidrogen, surya, arus laut, biomassa) menghadapi kendala yakni selain ketersediaanya terbatas, juga dihadapkan pada masalah investasi yang cukup mahal, sehingga harganya kurang 
kompetitif dibandingkan dengan jenis energi konvensional. Namun demikian pemerintah telah menetapkan konsep diversifikasi energi baik untuk energi fosil serta pemanfaatan semua jenis energi baru dan terbarukan hingga tahun 2025, yang tertuang dalam Blueprint Pengelolaan Energi Nasional 2005 2025. Dalam pemanfaatan energi ke depan faktor teknologi, ekologi dan ekonomi lebih diperhatikan, dalam rangka mewujudkan pembangunan berkelanjutan dan security of energi supply di masa datang ${ }^{[1]}$.

\section{PLTN DAN INDUSTRI PROSES MASA DEPAN}

Pandangan bahwa Indonesia adalah negara yang kaya sumber daya energi primer fosil, seperti minyak bumi, gas alam dan batu bara, adalah kurang tepat dan menyesatkan. Dilihat dari jumlah penduduk Indonesia berada diperingkat ke 4, akan tetapi dilihat dari besarnya cadangan sumber daya energi primer, Indonesia berada diperingkat bawah. Pemanfaatan secara besar-besaran sumber energi primer fosil ini tentunya menimbulkan kekhawatiran akan mempercepat kelangkaannya sehingga Indonesia harus tergantung pada energi yang diimport. Selain itu, akan timbul permasalahan lingkungan yang parah, baik disaat penambangan maupun di saat pemanfaatan, yang akhirnya menuntut biaya-biaya yang akan di bebankan pada para pemakai ${ }^{[2]}$.

Kebutuhan energi di sektor kelistrikan akan terus membutuhkan penambahan-penambahan pembangkit-pembangkit baru berskala besar. Ini berarti kebutuhan akan energi primer fosil untuk pembangkitan listrik akan terus meningkat, diperkirakan menjadi kurang lebih dua kali lipat setiap kurun waktu 10 tahun. PLTN sebagai salah satu jenis pembangkit berskala besar sudah sejak lama direncanakan untuk ikut memenuhi peningkatan kebutuhan listrik masyarakat. PLTN adalah teknologi tinggi, yang dalam konsep dan fenomena fisiknya berdasarkan hard science. Oleh karena itu wajar jika dalam introduksi PLTN di Indonesia ditinjau dari aspek public acceptance tidak mudah. Public education adalah salah satu cara untuk meningkatkan akselerasi realisasi PLTN pertama, agar pemerintah segera memutuskan atau mengijinkan untuk membangunnya. Perlu ditekankan juga bahwa aplikasi teknologi nuklir tidak hanya untuk PLTN. Namun PLTN adalah core bisnis teknologi nuklir.

Ditinjau dari aspek evolusi atau peningkatan kemajuan teknologi, regulasi dan strategi pengembangan jenis PLTN sebenarnya telah berhasil banyak menghilangkan 'keburukan' atau stigma PLTN yang telah ada sejak kelahirannya. Bahkan disain reaktor nuklir yang baru (Generasi IV) tidak hanya untuk PLTN namun juga sebagai sumber energi untuk proses industri, 
proses produksi bahan bakar lain yang sinergi dengan konsep-konsep konservasi lingkungan. Tentunya aspek keselamatan, keunggulan teknoekonominya juga semakin baik, terutama aspek penghematan bahan bakar nuklir. Dengan pandangan jauh kedepan, sudah tiba saatnya upaya mengurangi ketergantungan akan sumber energi primer fosil dan dengan serius mengembangkan sumber energi primer baru yaitu energi nuklir, sinergi dengan pengembangan energi baru dan terbarukan yang lain.

Hal penting yang perlu ditekankan adalah pemanfaatan nuklir ini memerlukan perlakuan khusus. Sehingga, usaha untuk pemanfaatan PLTN bukan business as usual akan tetapi menuntut perlakuan khusus melalui sebuah Nuclear Power Program (NPP). NPP adalah sebuah commitment bersama antara Pemerintah dengan sektor ketenagalistrikan, sektor industri (pabrikan), sektor rekayasa teknik dan lembaga-lembaga penelitianperguruan tinggi. Commitment ini adalah agar pengembangan PLTN di Indonesia berjalan dengan sebuah strategi yang tepat dan terbukti keberhasilannya ${ }^{[2]}$.

Keunggulan komparatif yang dimiliki oleh energi nuklir (PLTN) adalah dapat dibankitkan dalam skala besar sehingga biaya per satuan dayanya lebih murah dibanding pembangkit listrik yang lain. Operasi PLTN di negara maju telah terbukti, peran PLTN sangat besar dalam memenuhi kebutuhan listriknya, mendukung kebutuhan untuk proses industri, apalagi pada masa sekarang di mana harga BBM sangat tinggi. Di Amerika Serikat saat ini kampanye untuk meningkatkan pemanfaatan energi nuklir dilakukan gencar. Public information and education dimulai sejak anak-anak usia dini, melalui pendidikan dasar sehingga pemahaman yang obyektif mengenai IPTEK nuklir dapat diterima dengan baik. Mereka tidak bisa lagi meninggalkan PLTN untuk keperluan hidupnya, dalam mengembangkan pembangunan di sektor industri.

Sejarah perkembangan HTR (High Temperature Reactor) di Jerman banyak berimplikasi positif pada perkembangan IPTEK yang lain. Aplikasi material temperatur tinggi yang semula merupakan hasil-hasil penelitian pada masa HTR dikembangkan, saat ini telah dinikmati oleh industri lain terutama industri pembangkit listrik tenaga gas (PLTG/PLTGU). Dengan menggunakan material temperatur tinggi turbin gas yang diproduksi oleh Siemens AG dan ABB mampu beroperasi di atas $1000^{\circ} \mathrm{C}$ sehingga lebih efisien dari pada turbin gas generasi sebelumnya. Teknologi pengukuran temperatur temperatur tinggi dengan menerapkan instrumentasi modern dan presisi telah menyebabkan teknologi produksi bahan dapat dikendalikan lebih baik. Proses-proses sintesis bahan melewati teknologi keramik dan metalurgi 
serbuk telah menghasilkan banyak industri baru yang menggunakan bahanbahan struktur seperti pada HTR, antara lain ${ }^{[3]}$ :

a. Paduan $\mathrm{Ti}$ - Al, untuk keperluan komponen mesin turbin pesawat terbang. Paduan ini sangat tahan korosi pada temperatur tinggi dengan perubahan sifat mekanik yang tidak signifikan pada temperatur tinggi. Material ini sekarang dikembangkan dengan teknologi nano untuk mendapatkan kemudahan dalam proses sintering-nya.

b. Produksi komponen mesin yang dilakukan oleh Bayerische Motorwerk (BMW) dan Mercedes Benz, menggunakan Silikon Nitrida dan Silikon Karbida. Material ini dinilai tahan korosi pada suhu tinggi, sehingga motor bakar mampu beroprasi pada suhu tinggi dan dengan demikian akan dimiliki efisisensi lebih tinggi, lebih menghemat bahan bakar.

c. Fa. Schunk mengembangkan alat penukar kalor berbasis bahan grafit, dengan menggunakan sifat keunggulan grafit yang memiliki koefisien konduksi termal sangat tinggi, lebih tinggi daripada baja, namun lebih ringan dan kelimpahannya lebih banyak.

d. Teknologi filter keramik yang sekarang banyak dimanfaatkan untuk keperluan pengolahan air baik ultrafiltasi maupun reverse osmosis. Produk ini telah dikembangkan di Korea maupun Cina sehingga menjadi produk yang lebih murah dan dinikmati oleh masyarakat luas.

Kontribusi lain yang mengiringi perkembangan teknologi reaktor nuklir generasi IV, yang diawali oleh HTR di Jerman adalah dikembangkannya proses produksi hidrogen dari air yang sekarang diikuti oleh Jepang, Cina dan beberapa negara industri baru lainnya. Sekitar sebelum tahun 90-an banyak para peneliti dan mahasiswa dari Jepang, Cina dan Korea yang belajar teknologi HTR dan aplikasinya di Jerman. Saat ini mereka berkontribusi dalam mengembangkan dan menerapkan teknologi yang mereka pelajari itu untuk kepentingan negaranya, terutama dalam hal meningkatkan ketahanan energi di masa datang. Pada saat dan tempat yang sama melalui program kerjasama bilateral Indonesia dengan Jerman banyak pula para karya siswa dari BATAN yang belajar teknologi serupa. Mereka ini sesungguhnya merupakan modal besar untuk Indonesia ikut berperan mengembangkan teknologi reaktor maju. Sangat sesuai sekarang bagi Indonesia untuk kembali memanfaatkan para ahli itu, sehingga dengan memanfaatkan teknologi untuk berkontribusi menyelesaikan permasalahan bangsa terkait dengan kelangkaan sumber energi primer terutama BBM.

Afrika Selatan telah melanjutkan aplikasi HTR untuk memproduksi batubara cair menggunakan proses indirect liquefaction bersama dengan SASOL, sebuah industri yang sangat terkenal di bidang proses produksi bahan bakar. Pencairan batubara dilakukan dengan melalui fase dan proses 
gasifikasi menggunakan energi panas/kalor dari HTR. Teknologi itu sebelumnya telah dikembangkan dalam proyek terpisah di Jerman, yaitu HTR dan gasifikasi batubara peringkat rendah. Afrika Selatan yang kemudian menyatukan proses itu, kebetulan ahli dan penemu HTR tipe bahan bakar bola itu sering diundang unutk mengajar di sebuah universitas di Afrika Selatan. Mayoritas batubara di Indonesia adalah sejenis batubara peringkat rendah. Teknologi pemanfaatanya agar memberikan nilai tambah belum didefinisikan.

Pengembangan reaktor maju mutlak diperlukan bila nuklir akan tetap digunakan sebagai andalan teknologi pemenuhan energi. Untuk itu tidak harus menggunakan teknologi HTR. Reaktor nuklir generasi IV sebaiknya diarahkan pada konsep breeding, mengingat di masa mendatang pasti cadangan bahan bakar uranium akan habis pula. Penelitian-penelitian untuk mrndukung reaktor suhu tinggi - breeding akan mengatasi kelangkaan bahan bakar nuklir. Menurut sumber IAEA, cadangan uranium dunia akan habis dalam waktu sekitar 50 tahun bila digunakan untuk memenuhi kenutuhan reaktor nuklir dengan tipe LWR dan PHWR sekarang ini. Sekarang ini perdagangan uranium dunia sekitar 30 persen dipenuhi dari pertambangan dan proses ikutannya. Sedangkan sekitar 70 persen dipenuhi dari uranium yang semula direncanakan untuk senjata. Yang terakhir ini supply terbesar berasal dari Rusia. 50 tahun bukanlah masa yang panjang, tuntutan perkembangan reaktor nuklir pasti terjadi bila memang perkembangan energi terbarukan belum bisa kompetitif harganya. Dukungan energi nuklir akan bergeser tidak hanya untuk memproduksi listrik, namun akan mengarah pada sektor energi yang lain, energi terutama untuk mendukung proses produksi/industri dan transportasi.

Perkembangan teknologi reaktor nuklir baru berimplikasi pada persyaratan-persyaratan fisik, termal, mekanik, kimia dan neutronik yang baru pula. Selain itu umumnya juga merubah beberapa karakter berikut:

a. Instrumentasi temperatur tinggi, tingkat kehandalan dan presisi

b. Material baru, performance baik pada saat digunakan di reaktor nuklir

c. Sistem BOP (Balance of Plant)

d. Rekayasa Pengukuran

e. Industri Komponen Mekanik

Peluang untuk mengembangkan industri proses bahan semakin terbuka di Indonesia. Kekayaan alam, mineral dan energi merupakan modal besar bila ditopang dengan kemampuan penguasaan teknologi dan kebijakan pemerintah yang berpihak pada kemampuan dan kemandirian bangsa. Pada saat ini sedang dibahas rancangan undang-undang baru mengenai pertambangan mineral dan batubara. Undang-undang yang baru nanti 
diharapkan untuk mengganti undang-undang lama mengenai Pokok-pokok Pertambnagan no 11 tahun 1967. Dalam rancangan undang-undang itu mengenai mineral radioaktif disebut khusus, artinya mendapatkan perhatian besar untuk dikelola, tidak hanya ditambang dan dijual tanpa adanya nilai tambah, namun diolah, diproses untuk dikembangkan menjadi produk jadi atau setengah jadi.

Mineral lain yang merupakan sumber bahan baku industri logam sesuai dengan rancangan undang-undang pertambangan dan batubara yang baru lebih ditekankan untuk dikelola dan diolah agar dapat meningkatkan nilai ekonominya. Untuk itu industri proses dasar yang terkait dengan pemurnian, baik secara kimia maupun fisika sudah selayaknya dikembangkan. PTAPB Jogjakarta pernah mempelopori mengembangkan penelitian untuk mengolah mineral pasir zircon menjadi zirconium yang dapat digunakan untuk keperluan industri nuklir maupun non nuklir. Bila hidrogen diproduksi menggunakan reaktor maju dapat diproduksi secara komersial, dapat dipastikan kebutuhan zircon oxide, yang merupakan produk antara industri zirconium logam, akan sangat tajam meningkat kebutuhannya, yaitu untuk fuel cell. Fuel cell jenis SOFC diyakini paling efisien untuk digunakan sebagai alat konversi energi yang menggunakan bahan bakar hidrogen.

\section{MEMBANGUN KEAHLIAN}

Keahlian tidak dapat diperoleh hanya melalui pendidikan formal di perguruan tinggi. Keahlian diperoleh melalaui 3 tahapan yaitu:

a. Pendidikan

b. Pelatihan

c. Pengalaman kerja.

Pelatihan dan pengalaman kerja memiliki kontribusi besar terhadap keahlian seseorang. Oleh karena itu sertifikasi keahlian/profesi biasanya mensyaratkan antara lain aspek pelatihan atau pengalaman kerja. Untuk bidang IPTEK nuklir faham profesi dan sertifikasi ini telah berkembang sangat baik. Regulasi yang bernuasa sertifikasi dan profesi telah dikembangkan dengan mengacu standar internasional. Sesuai dengan resiko dan tingkat teknologi nuklir yang termasuk teknologi tinggi, persyaratanpersyaratan bagi seorang operator reaktor nuklir, atau petugas proteksi radiasi sangat ketat. Hal ini senantiasa digunakan unutk menjamin keselamatan aplikasi IPTEK nuklir itu sendiri.

Untuk bidang pendidikan, hingga saat ini pendidikan keteknikan di Indonesia banyak mengacu pada ABED 2005. Berikut adalah inti-inti acuan ABED 2005 tersebut $^{[4]}$. 


\section{ABET 2005 (Accreditation Board for Engineering and Technology 2005)}

\section{Engineering programs must demonstrate that their students attain:}

a. An ability to apply knowledge of mathematics, science, and engineering.

b. An ability to design and conduct experiments, as well as to analyze and interpret data.

c. An ability to design a system, component, or process to meet desired needs within realistic constraints such as economic, environmental, social, political, ethical, health and safety, manufacturability, and sustainability.

d. An ability to function on multi-disciplinary teams.

e. An ability to identify, formulate, and solve engineering problems.

f. An understanding of professional and ethical responsibility.

g. An ability to communicate effectively.

$\mathrm{h}$. The broad education necessary to understand the impact of engineering solutions in a global, economic, environmental, and societal context.

i. A recognition of the need for, and an ability to engage in life-long learning.

j. A knowledge of contemporary issues.

k. An ability to use the techniques, skills, and modern engineering tools necessary for engineering practice.

\section{KESIMPULAN}

a. Pengembangan keahlian memerlukan konsistensi dan komitmen kuat agar dapat memberikan kontribusi positif bagi penyelesaian masalah nasional, pembangunan berkelanjutan.

b. Pengembangan sumber daya manusia adalah investasi, sehingga perlu dimanfaatkan dan dibina sebaik mungkin guna kepentingan nasional menuju kemandirian bangsa.

c. Penguasaan terhadap ilmu dasar sangat penting guna mengembangkan industri yang berbasis pada keunggulan kompetitif, sumber daya alam dan mampu menguasai teknologi sesuai keahlian yang diperlukan untuk pengembangan industri.

d. Penguasaan IPTEK nuklir dasar sangat diperlukan untuk mendukung pengembangan reaktor maju dan aplikasinya sehingga menjadi alternatif solusi kebutuhan energi masa depan.

\section{DAFTAR PUSTAKA}

1. , 2005, "Blueprint Pengelolaan Energi Nasional 2005 - 2025”, Departemen Energi dan Sumber Daya Mineral, Republik Indonesia, Jakarta,. 
2. KUSNANTO, 2007, "Diskusi Terbatas HTR”, Jurusan Teknik Fisika Fakultas Teknik UGM, Jogjakarta,.

3. NAPITUPULU, E. dan AFFIF, A, 2006, "Prospek PLTN dalam Program Ketenagalistrikan Jawa-Madura-Bali (JAMALI) 2025”, Seminar Nasional Teknologi dan Keselamatan Reaktor, PTRKN - BATAN, Jogjakarta,.

4. SEDIAWAN, W. B., 2006, "Kurikulum Program Studi Teknik Kimia” Jurusan Teknik Kimia Fakultas Teknik, UGM, Jogjakarta. 
